Journal of Humanities, Social and Management Sciences (JHSMS)

eISSN: 2788-4791 (online)

https://doi.org/10.47264/idea.jhsms/2.1.14

Vol. 2, No. 1 (January-June 2021), 166-175

https://www.ideapublishers.org/index.php/jhsms

Research Article

\title{
Abrogation of Article 370 and 35-A, human rights situation in Indian occupied Kashmir and response options for Pakistan
}

\author{
Munazza Khalid*1-2 \\ 1. Department of Aerospace Sciences and Strategic Studies, Air University, Islamabad, Pakistan. \\ 2. Area Study Centre of Africa, North \& South America, Quaid-I-Azam University, Islamabad, Pakistan. \\ *Corresponding Author Email: munazzaqau@gmail.com
}

Received: April 19, 2021

Published: September 29, 2021

\begin{abstract}
Kashmir issue is a bone of contention between India and Pakistan since independence. One limited and three full-fledged wars have been fought between India and Pakistan. On August 05, 2019, India unilaterally abrogated Article 370 and 35-A of the Indian Constitution and made Kashmir it is part. Pakistan is continuously raising voice for the Kashmir cause and is making efforts to end the miseries of the people of Kashmir. This article is qualitative research in which a deductive methodology was adopted. Secondary data was used such as books, research articles, newspaper articles, reports, website articles and magazine articles. Descriptive and analytic technique is used. The findings show that abrogation of the two constitutional articles has severe consequences for South Asian strategic stability. Indian annexation of Indian held Jammu and Kashmir has resulted in human rights violations, killings, economic undermining, and social strangulation of the Kashmiri people. Pakistan needs to adopt different policy options provided in the article to resolve Kashmir issue because Kashmir is Pakistan's jugular vein. Peace and stability in Kashmir will bring peace and stability in South Asia and the world at large.
\end{abstract}

Keywords: Pakistan, India, Kashmir, Jammu and Kashmir, Constitution of India, Article 370, Article 35A, Peace in South Asia, Indo-Pak wars, human rights in Kashmir.

\section{How to Cite:}

Khalid, M. (2021). Abrogation of Article 370 and 35-A, human rights situation in Indian occupied Kashmir and response options for Pakistan. Journal of Humanities, Social and Management Sciences (JHSMS), 2(1), 166-175. https://doi.org/10.47264/idea.jhsms/2.1.14

\section{Publisher's Note:}

IDEA PUBLISHERS (IDEA Journals Group) stands neutral regarding jurisdictional claims in the published maps and institutional affiliations.

\section{Copyright:}

(C) 2021 The Author(s), published by IDEA PUBLISHERS (IDEA Journals Group).

\section{Licensing:}

This is an Open Access article published under the Creative Commons Attribution-NonCommercial 4.0 International License (http://creativecommons.org/licenses/by-nc/4.0/) 


\section{Introduction}

Kashmir issue is a bone of contention between India and Pakistan since independence. One limited and three full-fledged wars have been fought between India and Pakistan. On August 05, 2019 India unilaterally abrogated Article 370 and 35-A of the Indian constitution and illegally made Kashmir it's part (Ali, 2020). Article 370 of Indian Constitution had provided Kashmir the "power to have a separate constitution, a state flag, and autonomy over the internal administration of the state" (Ali, 2020). However, Article 35-A "protects the demographic status of the Jammu and Kashmir, which means that a person from other parts of India cannot purchase property in Kashmir" (Ali, 2020; Rauf \& Asif, 2021). Pakistan is resolutely struggling for the Kashmir cause and taking every possible step to culminate the problems of Kashmiris. Abrogation of these two articles has severe consequences for South Asian strategic stability. Indian belligerent annexation of Indian Held Jammu and Kashmir has negatively impacted Kashmir's solidarity and sovereignty. It has resulted in human rights violations, killings, economic undermining and social strangulation of the Kashmiri people.

Pakistan's has continued to respond both emphatically and clearly on the bilateral and multilateral levels at all regional international forums for the rights of the Kashmiri people. Pakistan has highlighted the Indian military operations and abuse of human rights at national and international forums. Pakistan has shown determination in supporting the people of Kashmir in their right of freedom and self-determination. This article presents various policy options which need to be pursued by Pakistan to resolve Kashmir issue because Kashmir is Pakistan's jugular vein. Peace and stability in Kashmir will bring peace and stability in South Asia and the world at large. The struggle for Kashmir needs to continue until the world acknowledged it and United Nation Security Council and international community exerted pressure to resolve the issue.

This article is using descriptive, analytical, qualitative and deductive research approach where theory of realism is used and applied. The objective of this study is to answer different questions such as, Why India abrogated article 370 and 35A of the Indian constitution? What is the genesis of the Kashmir conflict? What advantages India would get from this abrogation act and the inhuman activities in Kashmir? What policy options and responses Pakistan needs to adopt to resolve this issue? The rest of the paper is organized as follow: Sections 2 gives a brief overview of the literature. Section 3 describes the theoretical framework of the study. Sections 4 explains the research methodology. Sections 5 is focused on the discussion and analysis of the study. Section 6 concludes the paper.

\section{Literature review}

Kashmir is the bone of contention between Pakistan and India since the time of partition of Indian subcontinent in 1947. Kashmir issue led towards fighting three full-fledged wars between India and Pakistan and one limited war at the time of Kargil crisis. China is involved as a third party in the Kashmir dispute (Ali, 2020). India and Pakistan both claim the entirety of the state of Jammu and Kashmir. India controls approximately 55\% of the area of the region and $70 \%$ of its population; Pakistan controls approximately $30 \%$ of the land, while China controls the remaining 15\% (Ali, 2020). India administers Jammu, the Kashmir Valley, Ladakh, and the Siachen Glacier which was militarily occupied by India on 13 April 1984 (North, 2014). India annexed Assam, Tripura, and Manipur after 1947 and captured Goa in 
Abrogation of Article 370 and 35-A, human rights situation in Indian occupied Kashmir ...

1961 and now illegally made IOK as its part. Pakistan administers Azad Kashmir and GilgitBaltistan. China administers the mostly uninhabited Shaksgam Valley, and the Aksai Chin region. Kashmir is having twelve-millions of populations out of which nine million resides in IHK and only three million are living in Azad Kashmir (Gershman, 2001). Kashmir conflict "involves an area of about 222,236 Km²" (Akhtar et al., 2021).

On $5^{\text {th }}$ August 2019, firstly, both houses of the Parliament of India passed resolutions to abrogate Article 370 and implement the Indian constitution on the State of Jammu and Kashmir. Secondly, Indian parliament passed the Jammu and Kashmir Reorganization Act, 2019, which would dismiss the state of Jammu and Kashmir and bifurcate it into two different union territories. Jammu and Kashmir are separated from Ladakh. This Re-Organization Act was approved by both houses of parliament and Indian President and was enforced on $31^{\text {st }}$ October 2019. Indian government implemented strict security measures before $05^{\text {th }}$ of August 2019 to avoid any trouble in Kashmir. For instance, longest lock down was implemented which prolongs till to date (Fareed \& Krishnan, 2020). Additionally, Indian government had imposed section 144 in the valley to restrict movement and congregation of the Kashmiris. Furthermore, the internet service and mobile phone services were also blocked. Moreover, the political leaders such as "Chief Ministers Omar Abdullah and Mehbooba Mufti" were under house arrest. Reportedly thousands of Kashmiris; specially youth, were rounded up and sent to various jails in the Indian mainland.

Article 370 of Indian Constitution provides Kashmir the "power to have a separate constitution, a state flag, and autonomy over the internal administration of the state." However, Article 35A "protects the demographic status of the Jammu and Kashmir, which means that a person from other parts of India cannot purchase property in Kashmir". Pakistan is the only states that is brilliantly fighting for the Kashmir cause and taking actions to finish the miseries of Kashmiri people (Ali, 2020). However, Pakistan is facing economic, social and security related problem at home. Pakistan needs to increase its diplomatic efforts against the illegal abrogation of articles of 370 and $35 \mathrm{~A}$ and should make efforts to highlight the human right violation in-front of media, international community and international organizations (Ali, 2020). Indian abrogation of Article 370 and 35-A regarding Kashmir are damaging its reputation (Shah \& Shah, 2020). Pakistan, Turkey, Malaysia and China raised their voices against this Indian act. However, many states consider Indian act as its internal matter. Turkey, Malaysia, other Muslim and western states suggested the dialogue process between Pakistan and India to resolve this issue (Shah \& Shah, 2020).

India adopted the Israeli model of seizing Kashmiri identity and robbing the Kashmiri autonomy (Minhas et al., 2019). Indian move also resembles Russian model of annexing Crimea-Ukraine. India always portrayed Kashmiri freedom struggle as violence or extremism but after this Indian act this Indian narrative was proved wrong. It was proved that; India is the aggressor and is using different tactics to control Kashmir. Kashmiri people want freedom from Indian oppression and don't want to tolerate the Indian abrogation of Article 370 and 35-A. UNSC passed many resolutions on Kashmir (such as UNSCR 38, 39, 47, 51, 80, 91, 96, 98, $123,209,210,211,214,215,303$ and 307) and decided to hold plebiscite and give the right to Kashmiris to decide their own future. But, over a period of time, international community has lost interest in resolving the issue for apparently three reasons: First, India is largest democracy; second, India is having biggest market; and third, India is countering the rise of China in region (Minhas et al., 2019). 


\section{Theoretical framework}

Theory of Realism is used to address the Indian role in Kashmir issue. Thucydides in $5^{\text {th }}$ century B.C. provided the basics of realism in his writing "History of Peloponnesian War" (Griffiths, 2007). He provided the significance of power in politics. Power dictates the behaviour of states. The difference between strong and weak state is described through the conversation between Athenians and Malians. The conclusion drawn from this dialogue is that weak has to suffer and obey the strong and strong has right to do what it wants (Griffiths, 2007). In order to become dominant, states kept on increasing power. India wants to dominate in Kashmir. It is the stronger than the Kashmir. Being a strong party, it abrogated the Article 370 and 35A to get hold over the Kashmiri territory and to maintain and maximize power in Kashmir.

Kautilya, the minster of Mauria dynasty at Taxila, in his writing Arthashastra focused on the concept of balance of Power needed for survival. The aim of states is not only to secure itself but also to expand its territory. States aim to seize or annex the territory of other (especially neighbour i.e., Kashmir) to enhance its capabilities, power and resources. For this purpose, India took action of abrogation of the articles. Absence of Balance of Power gives the powerful state free hand to follow self-motivated foreign policy. Kashmir is weaker than India and it gave India free hand to pursue self-motivated foreign policy. India abrogated the article, seized the territory and violated the human right of Kashmiri people.

\section{Research methodology}

This article adopts qualitative research methodology. Deductive research methodology was adopted, where theory of realism was successfully applied in the case of Indian role in Kashmir conflict. Secondary data was utilized such as books, research articles (from different online sources such as Google scholar, Google, ISI Web, online libraries, HEC digital library, and Wiley online library), newspaper articles, reports, website articles and magazine articles. Descriptive and analytic technique is used.

\section{Discussion and analysis}

\subsection{Background genesis and history of Kashmir dispute}

Kashmir Dispute emerged at the time of partition of Indian Subcontinent. The British gave the choice to either side with Pakistan or India. Kashmir's ruler was non-Muslim (i.e., Hari Singh) and majority of people were Muslims. Muslim majority of Kashmir decided to be part of Pakistan and the Hari Singh decided to join hands with India (Minhas et al., 2019). Maharaja Hari Singh sought military help from India. Both India and Pakistan intervened in Kashmir to get hold of the entire Kashmir. Subsequently, the Maharaja signed the "Instrument of Accession" with India in October 1947 (Akhtar et al., 2021). The first Kashmir war started on 27 October 1947 and lasted till January 1, 1949. United Nations intervened and UNSC passed the Resolution-47 on April 21, 1948 to hold plebiscite in Kashmir. India managed a ceasefire with a promise to hold plebiscite to give the right to Kashmiris for deciding about their status. Skirmishes again occurred and UNSC adopted a Resolution-80 on Kashmir on March 14, 1950 to immediately demilitarization of Jammu and Kashmir (Minhas et al., 2019).

The unresolved issue of Kashmir led to the outbreak of a full-fledged conventional war over 
Abrogation of Article 370 and 35-A, human rights situation in Indian occupied Kashmir ...

Kashmir on September 6, 1965. Later, on September 23, 1965 ceasefire took placed. India after that shifted its attention towards separating East Pakistan from West Pakistan (Ali, 2020). Political instability resulted after the 1971 election. Modi admitted that India supported the Mukti Bahini, a Bengali separatist organization as a tool to divide Pakistan and that resulted in formation of Bangladesh as a separate nation. India used the factors of political disharmony and geographical disconnect against Pakistan in 1971 (The News, 2015).

In July $2^{\text {nd }}, 1972$ Simla agreement was signed between India and Pakistan to resolve the Kashmir issue bilaterally through dialogue. Simla agreement established the de-facto boarder (between Indian and Pakistani controlled Kashmir) which is named as Line of Control (LoC) (Wenning, 2003). Simla agreement has fulfilled the Indian desire of keeping the Kashmir issue bilateral instead of resolving it through plebiscite. Later, the Afghan war of 1989 postponed the Kashmir resolution (Minhas et al., 2019). The nuclear tests of 1998 led to the re-emergence of Kashmir issue. In 1999 the Kargil conflict took place, but the international community intervened and the war remained the limited war instead of escalating it to the nuclear war (Minhas et al., 2019).

The term of terrorism was noticed after the incident of 9/11 and the Kashmiri freedom struggle is painted as terrorism (Minhas et al., 2019). Friendly relations between India and Pakistan were noticed in 2004 where Vajpayee and Musharraf issued joint statement to resolve the issue through dialogue. CBMs were noticed in PM Manmohan Singh's time as well. Bus service was started and the tension over Kashmir issue declined (Shah \& Shah, 2020). Since 2016, because of Modi's Hindutva ideology there has been no chance of diplomatic engagement between India and Pakistan (Shah \& Shah, 2020).

The martyrdom of Kashmiri freedom fighter Burhan Wani enhanced the freedom struggle in 2017. Pakistan brought this matter in front of UN to turn international community against India (Minhas et al., 2019). But Pakistan failed in getting support because of India's economic strength, effective diplomacy and its strong hold on media (Shah \& Shah, 2020). India is having an edge over media (Minhas et al., 2019). BJP has adopted the RSS purely Hindutva's ideology (Shah \& Shah, 2020). It adopted the manifesto of revoking the Kashmir's special status in the second time election campaign of Modi administration. In the end of February 2019, Pulwama incident happened. After winning second time, Modi government unilaterally took the decision to abrogate the article 370 and 35A of the Indian constitution and imposed strict curfew in IOK (Minhas et al., 2019). At the same time, India halted all communication, civilian movements and political leaders are restricted under house arrest.

\subsection{General implications of revoking article 370 and $35 \mathrm{~A}$}

The Indian undemocratic and immoral act of seizing the Kashmiris autonomy and their identity would be having following implications. Firstly, the freedom struggle would become bloodier. It is noticed from the "Rights Group report of July that, Indian-occupied Kashmir had seen at least 229 killings during more than 100 abrogation of Article 370 and 35-A since January 2020" (Dawn, 2020). There is a chance that the incidents of killing can be increased in Kashmir. Thirdly, Kashmiri economy would be affected badly. Because of the "communications blockade, curfews, and militant threats, the economy of Kashmir lost INR 178.78 billion". More than 90,000 people lost jobs in Kashmir especially in the field of handicraft, tourism and information technology because of the internet blockade and the 
Indian abrogation of Article 370 and 35-A (Wani, 2020). This is the first greatest economic slowdown in Kashmir since last 70 years (Wani, 2020). Fourthly, due to this long curfew, Indian government has denied educational facilities to the Kashmiri students, thus turning their future into darkness. They instead of getting education and representing Kashmir cause in international forums, the students have remained at home and barred from using internet for education. Students are wasting time and they are forced to pay INR 100 to 200 per online submission at Indian offices (Wani, 2020). IOK faced 55 internet shutdowns in first six month of 2020 (Dawn, 2020).

Fifthly, India will launch genocide to curb insurgency (Minhas et al., 2019). Sixthly, India is imposing demographic changing by giving non-Kashmiri people the domicile of Kashmir to convert Muslim majority into a minority. The Rights Group report showed that "India has granted tens of thousands of people from outside the region the same rights as Kashmiris". They are allowed to buy land for the first time. This Indian endeavour is the attempt to change the demographic situation of the Kashmir (Dawn, 2020). Seventh, India is blaming Pakistan that it is supporting Kashmiri freedom struggle (Minhas et al., 2019). Indian allegation and its efforts of destroying Pakistani image would lead towards war amid them. It is reported that during the first five months of the 2020, India has committed 957 ceasefire violations and targeted innocent civilians in Azad Jammu and Kashmir while in 2019, 3000 cases were noticed (Ashraf, 2020).

\subsection{Analysing Pakistan's response}

Pakistan's initial response was limited to telephonic diplomacy (Ali, 2020). For instance, Imran Khan was having conversation with Iranian counterpart and the statement came from Iranian side that Kashmir does not have a military solution (Shah \& Shah, 2020). Later, PM Imran Khan twice visited to US and also delivered a speech in UNGA. Pakistan effectively engaged with representations of other countries to highlight the Kashmir issue. It was Pakistan's success that PM of Malaysia, President of Turkey and Foreign Minister of China immensely condemned Indian abrogation of Article 370 and 35-A regarding Kashmir and demanded peaceful solution in the UN General Assembly session held in September 2019 (Ali, 2020). It is the need of time that Pakistan should improve its bilateral relation with other states to get support from them. There is no need to relay only on verbal statements.

Different practical steps are required. Pakistan needs to build narratives. Indian FM Jay Shankar has built many narratives against Pakistan and declaring Pakistan as a supporter of terrorism in IOK (Ashraf, 2020). Pakistan's foreign office and its diplomatic personnel need to reform this narrative and proposed its own narrative. Pakistan needs to urge UNO to pass resolution and resolve the issue. For this purpose, Pakistan needs to improve its relations with world and urge other states to understand the Pakistani and Kashmir position and notion. However, India is cunning at diplomatic front. It knows how to divert the attention of the international community. Pakistan needs to reveal the true face of India and Modi. Modi was refrained from entering into US and Canada for 12 years after the Pogrom incident of Gujarat in 2005 (Rauf \& Asif, 2021). Pakistan needs to show this Modi face to media and international community and show the world about Indian human rights violation, genocide and abrogation of Article 370 and 35-A regarding Kashmir. Pakistan needs to show this religious and racial extremist face of Modi to international community. 
Abrogation of Article 370 and 35-A, human rights situation in Indian occupied Kashmir ...

Pakistan needs to prepare itself for diplomatically move and remained prepared to cater/handle any confrontation (Ali, 2020). At national level, Pakistan's National Assembly unanimously passed the resolution on August 2019 and rejected the Indian act and urge the world to take steps against Indian aggression. Pakistan sent the Indian High Commissioner back to India. Pakistan ended its bilateral trade, Dosti Bus and Samjhota Express Train Service. Pakistan declared Indian Independence Day as black day (Minhas et al., 2019). At diplomatic front, Pakistan arranged back-to-back meetings with diplomats of other states. Pakistan approached UNSC and Human Rights Council to consider and inquire Kashmir issue (Minhas et al., 2019). UNSC conducted a meeting on Kashmir issue, but no consensus was made, and no official statement or resolution was adopted in that meeting. Pakistan requested the OIC meeting. Turkey and Iran supported Pakistan's opinion. However, UAE and KSA considered economic gain more important than calling the OIC meeting on Kashmir. Because the annual trade between Gulf Arab countries and India is approximately 100 billion dollars (Minhas et al., 2019). Government of Pakistan needs to activate and empower the Government of Azad Jammu and Kashmir. With status of a government representing the people of $J \& K$, it can present its case to the whole World. It can muster the political, diplomatic, economic, social and human rights support effectively.

\subsection{Broad policy response options and way forward for Pakistan}

There are many options available for Pakistan that need to be adopted. Pakistan should remain rational, focused and logical while selecting any measure. Pakistani decision maker can consider following modus operandi. It is required that Kashmiri and Pakistani people don't get distracted from Kashmiri struggle. Otherwise already set goals could disappear. Pakistan needs to increase the economic development and trade because the voice of strong economy can only be heard. Pakistan needs to clarify that Pakistan is not sponsoring terrorism in Kashmir by building its own narrative and elucidating that Indian narrative is biased. Pakistan needs to tell the international community that it is only providing the moral and diplomatic support to Kashmir cause. So that their confusion can be corrected, and trust can be developed, and international community open-heartedly supports Pakistan on resolving Kashmir issue.

It is required that Pakistani and Kashmiri diaspora play their role in western nations through holding meeting in their parliaments and senates; by arranging seminars and by discussing this issue in their Think-Tanks and international forum. Pakistan needs to raise its voice in international forums and bring their attention towards this issue to get proper official statement or resolution for resolving this issue. Pakistan needs to highlight devastating human rights and security issues prevailing in Kashmir through media, by publishing unbiased reports, or by arranging visits to Kashmir valley. Pakistan should establish a tri-party committee comprising of Kashmiri reps from both Azad Kashmir and Indian-held Kashmir, China and Pakistan to issue joint statements on evolving situations inside Kashmir. Pakistan needs to extend its diplomatic outreach to get more favourable votes in own favour at international level. Pakistan should employ a strong media campaign to project its own narratives while mitigating propaganda campaign of the Indian media. It is important for Pakistan to activate Pakistani Missions Abroad. Pakistan needs to open Kashmir Study Centers in Universities in Pakistan and in brotherly and friendly countries like Turkey, Iran, Malaysia, China, Russia, Japan and other friendly nations.

The Non-Kinetic warfare (including media war) is mandatory to win the support in current era 
(Ali, 2020) and Pakistan is good at it (Minhas et al., 2019). Pakistan needs to use it for resolving this issue. It is important to inform the nation and provide them up-to-date info through pressbriefing or by political, diplomatic, military and media channels. It is important that nation should be taken into confidence, so that unity at national level could be accomplished. Harmony between civil-military hierarchies has to be maintained at all costs. It is better to avoid giving aggressive statement because it will negatively affect Pakistan's image. Nuclear weapons can be used as a threatening element but should be consider as a last resort. Government of Pakistan should try to initiate dialogues, CBMs and Strategic Restraint Regime (SRR) to resolve the issue bilaterally. Religious, social and political harmony is required in Pakistan and Kashmir (Ashraf, 2020).

Pakistan should arrange visits of the international experts and human rights bodies to Azad Jammu \& Kashmir, so that they can get the clear picture of Indian abrogation of Article 370 and 35-A regarding Kashmir, and they see Indian Violation of Human Right and International law. After knowing the true face of Indian aggression and abrogation of Article 370 and 35-A regarding Kashmir, all the international community would hopefully stand against India. Pakistan should issue the unbiased Human rights violation report and research to throw light towards Indian illegal and fascist involvement in the Kashmir. In India-Pakistan case, the chances of using military option cannot be ignored. However, use of military option should be the last resort, otherwise Pakistan will lose international support. The practical steps include the appointment of competent diplomat as a head of Kashmir Cell to redefine the roadmap of resolving the issue by engaging international community. This Cell can invite media and Parliament members of other states to visit Kashmir and give them detailed briefing. Shah Mahmood Qureshi announced in 2019 to establish the Kashmir Cell. This Cell is quite recent. However, Pakistan already has "The Parliamentary Special Committee on Kashmir" which is performing the duty of raising the critical issues of Kashmir at national and international level. This committee is composed of senior MNAs and Senators of Pakistan. Government of Pakistan needs to adopt national consensus over the Kashmir issue and arrange national dialogue conference where all political parties, executive, military and judiciary should become unite on one page (Ali, 2020).

Two years has passed after the abrogation of Article 370 and 35A and Kashmir is still under siege (Awan, 2020). India is violating human right and making people imprisoned, killing youth and using rape as a war tactics or weapon of war against Kashmiri women (Idrees et al., 2021). International media is silent. The issue should be taken to the international criminal court. Pakistani narrative should be built strong so to be heard. Pakistan needs to write letters and convey the true face of India. Pakistan is not to be considered as aggressor. India and Pakistan signed the agreement on June 4, 2002 and remained part of principle of selfdetermination struggle. The issue of rape, killing and genocide would be taken to international criminal court. UNSC passed the October 2002 resolution to avoid rape element as a weapon of war. There is a need to appeal Women organization to see the issue and raise the voice against Indian abrogation of Article 370 and 35-A.

Civil society should become active and Kashmiri diaspora is strong electoral force in Western states. They can influence their country i.e., UK and Denmark etc. Pakistan needs to keep highlighting and pointing out the issue to the world, so that someday it can be heard. Institutional follow-up must be carried out. It should be highlighted that people of Kashmir would not accept the Indian act of revoking Article 370 and 35A. Kashmir issue would be taken 
Abrogation of Article 370 and 35-A, human rights situation in Indian occupied Kashmir ...

again to international forum to get resolution for resolving the issue. Ground realties are strange because for states, interest matters instead of realities of Kashmir issue.

In the presence of cold-blooded realities, two ways are available, first, Kashmiri people remain stuck with their internal struggle. Secondly, Pakistan keeps on taking different steps and highlighting the issue. As Ambassador Retired Riaz Hussain Khokhar pointed out the fact in conference held at $5^{\text {th }}$ August 2020 in QAU, that there is the need to provide full spectrum support to Kashmir (not in military term) (Kashmir Conflict in the Post August 2019 Scenario, 2020). If international community is not addressing the issue, do not expect any concession from them because states follow their interests. Their conscious is dead. It is better to take steps politically and our military should remain prepared for any future scenario. Because it is difficult to predict future, but it is better to remain prepared for future to avoid negative situation. We need to put our house in order, get mandate from Parliament, take all institutions on board especially MOFA, MOD, Parliament, Opposition, judiciary, Armed forces and warfighting corps. Hope for the best and prepare for the worst.

While dealing with Kashmir issue be confident and don't bear the extra baggage. For instance, India can lower down Pakistani struggle by linking Kashmir issue with Baluchistan or GilgitBaltistan. It is Pakistan's responsibility to remain stuck to Kashmir cause because these are Indian wily strategies to refrain Pakistan from fighting for Kashmir cause. Pakistan needs to fight at all levels, so that Kashmiri get motivated and they don't give up. There is need to take practical steps instead of beating about the bushes. Pakistan needs to adopt the UN 2005 mandate of Responsibility to Protect (R2P) to protect Kashmiris from Indian abrogation of Article 370 and 35-A because 20 million Kashmiri people have the right to live with dignity.

\section{Conclusion}

Kashmir is the jugular vein of Pakistan, which cannot be ignored. Since independence it remained bone of contention between Indian and Pakistan. Indian abrogation of Article 370 and 35-A regarding Kashmir since August 2019 increased manifold. Pakistan needs to adopt different measures highlighted in the article to resolve the issue. Kashmiri people need Pakistan's support and Pakistan has to provide them the support. Peace and security of Kashmir is the pre-requisite for security and stability of the South Asian region. A well addressed and timely strategy needs to be adopted. Pakistan and Kashmir need to remain with their struggle until and unless the world acknowledged it and UNSC intervenes and resolves the issue. Meanwhile, let's hope for the best and prepare for the worst.

\section{References}

Akhtar, D., Hussain, F., Nawaz, S., \& Haider, S. (2021). An analysis of Pak-India rivalry over Kashmir dispute: A conflict resolution approach. Elementary Education Online, 20(3), 1979-1986. https://www.bibliomed.org/mnsfulltext/218/2181618630200.pdf?1632074637

Ali, S. (2020, June 04). The Kashmir conundrum- post Indian abrogation of Article 370 and 35a: The way forward. South Asia Journal. http://southasiajournal.net/the-kashmirconundrum-post-indian-abrogation-of-article-370-and-35a-the-way-forward/. 
Ashraf, M. (2020, June 5). Kashmir continues to bleed. The Nation. https://nation.com.pk/05Jun-2020/kashmir-continues-to-bleed

Awan, Z. (2020, August 02). One year siege of Kashmir. Modern Diplomacy. https://moderndiplomacy.eu/2020/08/02/one-year-siege-of-kashmir/.

Dawn. (2020). One year of India's clampdown in occupied Kashmir - Here's everything you need to know. https://www.dawn.com/news/1514652

Fareed, R., \& Krishnan, M. (2020, August 04). Kashmir: A year of lockdown and lost autonomy. Deutsche Welle.com. https://www.dw.com/en/kashmir-a-year-oflockdown-and-lost-autonomy/a-54437369

Gershman, J. (2001). "Overview of Self-Determination Issues in Kashmir." Foreign Policy in Focus. Accessed at http://www.selfdetermine.org/conflicts/kashmir.html>.

Griffiths, M. (Ed.). (2007). International relations theory for the twenty-first century: An introduction.

Routledge. https://hostnezt.com/cssfiles/internationalrelations/International-Relations-Theoryfor-21st-Century.pdf

Idrees, R. Q., Imran, M., \& Jamil, T. (2021). The Indian occupied Kashmir dispute: A legal analysis in purview of United Nations Resolutions. Pakistan Journal of International Affairs, 4(1). 105-123. https://doi.org/10.52337/pjia.v4i1.39

Kashmir Conflict in the Post August 2019 Scenario. (2020). In Kashmir conflict in the Post August 2019 Scenario. Office of the Dean Faculty Social Sciences Quaid-I-Azam University, Islamabad. https://www.facebook.com/watch/live/?v=308256230419537\&ref=watch_permalink

Minhas, A., Ahmad, B., \& Khan, M. (2019). Seizing Kashmir's identity: Implications for the global peace and stability. NDU Journal, 63-82. https://ndu.edu.pk/ndu-journal/pubnew/04-Seizing-Kashmir.pdf

North, A. (2014). Siachen dispute: India and Pakistan's glacial fight. BBC News. https://www.bbc.com/news/world-asia-india-26967340

Rauf, S., \& Asif, M. H. (2021). Modi and Imran regime: Foreign policy on Kashmir dispute. Human Nature Journal of Social Science, 1(1), 60-69. http://hnpublisher.com/ojs/index.php/HNJSS/article/view/3

Shah, K., \& Shah, K. (2020). Kashmir after Article 370: India's diplomatic challenge. Observer Research Foundation (ORF) Occasional Paper No. 259. https://www.orfonline.org/research/kashmir-after-article-370/

The News. (2015, June 08). Indian forces fought along Mukti Bahini: Modi. https://www.thenews.com.pk/print/12923-indian-forces-fought-along-mukti-bahinimodi.

Wani, A. (2020). Life in Kashmir after Article 370. Observer Research Foundation (ORF), Special Report No. 99. https://www.orfonline.org/research/life-in-kashmir-afterarticle-370-60785/

Wenning, H. (2003). Kashmir: A regional conflict with global impact. New Zealand Journal of Public and International Law, 1(1), 197-227. https://search.informit.org/doi/abs/10.3316/INFORMIT.794913540374698 